\title{
MODERNIDADES "PERIFÉRICAS", LITERATURAS POLICÊNTRICAS: DOSTOIÉVSKI, MACHADO DE ASSIS E O "FIGURINO" EUROPEU
}

http://dx.doi.org/10.11606/issn.2237-1184.v0i24p44-67

\author{
Ana Carolina Huguenin Pereira \\ Universidade Estadual do Rio de Janeiro (URJ)
}

\section{RESUMO}

F. Dostoiévski e Machado de Assis reelaboraram, através da literatura, os contextos históricos de países que se modernizavam combinando influências estrangeiras às próprias tradições. A partir dos anos $1880 \mathrm{a}$ literatura russa passou por processo de grande difusão internacional, multiplicando-se a influência das obras dostoievskianas, inclusive no Brasil. Neste contexto, a produção literária de um país considerado "periférico" em relação aos centros industriais europeus transportouse das "margens" - simbólicas e fronteiriças - para ocupar lugar de destaque no "centro" da modernidade oitocentista. O artigo defende que a modernidade, enquanto processo histórico amplo, não guarda "centros" estáticos, mas engloba grande variedade humana em múltiplos diálogos.

\section{ABSTRACT}

F. Dostoyevsky and Machado de Assis recreated through literature the historical context of their countries during modernizing periods, which combined western influences and national traditions. In the 1880's Russian literature went through a vast international diffusion, increasing Dostoyevsky's artistic influence worldwide and in Brazil. In this context, the literature produced in a "Peripheral" country went from the symbolical and geographical "margins" of modern world to it's very "center". This article intends to discuss modernity as a multiple, ambiguous process, not having static centers, but rather involving a great human variety within a multiple dialogue between different nations.
PALAVRAS-CHAVE:

Literatura Russa.

Modernidade.

Dostoiévski.

Machado de Assis.

KEYWORDS:

Russian Literature.

Modernity.

Dostoyevsky.

Machado de Assis. 
"Porque tudo, decididamente quase tudo o que em nós existe de desenvolvido, ciência, arte, cidadania, humanismo, vem de lá, daquele país das santas maravilhas!

[...] Será possível que algum de nós tenha podido resistir a essa influência, a este apelo, a esta pressão?

Dostoiévski. Notas de inverno sobre impressões de verão.

"Preguiçoso e subdesenvolvido" [povo russo], os senhores repetem. Notem, cavalheiros, que todos esses nossos elevados professores europeus - nossa luz e nossa esperança-todos esses Mills e Darwins e Strausses por vezes tem uma visão muito estranha das obrigações morais de uma pessoa dos dias de hoje. [...]. Quando se fala de nossos inteligentes e ardentes jovens estudantes, é difícil imaginar que possam não entrar em contato com tais nomes desde os primeiros passos na vida. Pode a juventude russa permanecer indiferente à influência desses líderes do pensamento progressivo europeu e particularmente ao aspecto russo de seus ensinamentos? Permitam-me usar essa expressão engraçada: 'o aspecto russo de seus ensinamentos', porque tal aspecto de fato existe [...]. Consiste nas conclusões retiradas desses ensinamentos que tomam forma de invencíveis axiomas, e que se dão somente na Rússia; na Europa, dizem, a possibilidade de tais conclusões não é nem suspeitada. Dostoiévski. Diário de um escritor, 1873.

\section{— Os "professores europeus" e o "prisma russo"}

Foi com profundo senso crítico que F. M. Dostoiévski refletiu a respeito das influências da Europa Ocidental ("nossa luz e nossa esperança", ou "tudo o que em nós existe de desenvolvido") sobre a Rússia de seu tempo - questões discutidas, entre aguerridas polêmicas, polarizações e improváveis interseções, pela intelligenstsia russa. No contexto do debate, o autor se posicionou através da atuação jornalística - enquanto editor dos periódicos Tempo, Época e Diário de um escritor - e da atividade literária, enquanto romancista cuja obra, ainda nos oitocentos, extravasou as fronteiras do Império tsarista para ganhar popularidade a oeste, na terra das "santas maravilhas". A expressão é utilizada ao longo de Notas de inverno sobre impressões de verão (1863) relato da primeira viagem de Dostoiévski ao ocidente europeu - e faz referência ao poema "Sonho" (Metchtá, 1835) do pensador eslavófilo A. Khomiakóv. Diz o poema: "Oh, eu me entristeço! / Uma sombra espessa deita-se/ Sobre o distante Ocidente/ $\mathrm{Na}$ terra das santas maravilhas [ $\mathrm{Na}$ strane sviatikh tchudes]. ${ }^{1}$

${ }^{1}$ KHOMIAKOV, Aleksei. S. Izbrannoe. Tom 1. Tula: Peresviét, 2004, p. 277. 
As Notas trazem as impressões de Dostoiévski em viagem pelo centro precursor e difusor da modernidade industrial, cultural e política. Em sua passagem pela França e pela Inglaterra, o viajante perfila duras críticas ao capitalismo, às desigualdades sociais e à busca irrefreada pelo lucro. Neste sentido, destacam-se os capítulos "Baal" e "Ensaio sobre o burguês", a respeito das sociedades londrina e parisiense, respectivamente. As Notas são pontuadas pelo o "êxtase e o horror" ${ }^{2}$ que ligavam o literato russo, como muito de seus pares, ao ocidente europeu. Embora Dostoiévski critique o modelo de civilização ocidental, apontando, por vezes com ironia, por vezes através de arroubos de indignação moral, a "espessa sombra" que acompanharia as "santas maravilhas", as últimas contribuíram para moldar sua formação intelectual e artística. Foi em seu nome - ideais de liberdade e a igualdade - e contra os "santos" horrores russos - a servidão (abolida no ano anterior à viagem, em 1861), os castigos corporais e a rígida hierarquia social - que o autor foi encarcerado na "casa dos mortos", cumprindo quatro anos de trabalhos forçados em presídio militar na Sibéria Ocidental. Após "ressuscitar" e retornar à vida literária, sob o reinado modernizador de Alexandre II (1855-1881), Dostoiévski aproximou-se da eslavofilia e passou a defender com paixão certas tradições russas - mais especificamente, o cristianismo ortodoxo e a comuna camponesa ${ }^{3}$. Não obstante, permaneceu um crítico vigoroso das injustiças e desigualdades que marcavam o contexto em que viveu - basta termos em vista os quadros dramáticos que ilustram a vida dos "humilhados e ofendidos", onipresentes na obra dostoievskiana.

A exemplo de seus conterrâneos ocidentalistas e eslavófilos, o romancista era parte de uma elite intelectual profundamente influenciada por parâmetros artísticos e filosóficos ocidentais - o "nosso grupinho privilegiado e patenteado", distante dos "russos de modesta condição [...] que se chamam cinquenta milhões [...], e a quem nós, que somos cem mil, até agora consideramos como sendo ninguém" "Ciência, arte, cidadania, humanismo", ou "tudo o que nos existe de desenvolvido", em um país "subdesenvolvido" (niedorazvitkii) ${ }^{5}$ viria da "terra das santas maravilhas", de acordo com o que repetiriam "cem mil" "cavalheiros" empenhados em reconfigurar o Império e adequar a educação de "nossos ardentes jovens" a parâmetros ocidentais.

"Esses Mills e Darwins", entre outros autores "líderes do pensamento progressista europeu", insinuavam "novas ideias" vinculadas a grandes transformações econômicas, culturais e científicas em curso a oeste, nos quadros da criação e expansão de uma nova ordem

\footnotetext{
${ }^{2}$ DOSTOIÉVSKI, Fiódor. O crocodilo e Notas de inverno sobre impressões de verão. Trad. Boris Schnaiderman. São Paulo: Ed.34, 2000, p. 69.

${ }^{3}$ WALICKI, Adrzej. The slavophile controversy: history of a conservative utopia in nineteenth century russian thought. Oxford: Clarendon Press, 1975.

${ }^{4}$ DOSTOIÉVSKI, Fiódor. Notas de inverno sobre impressões de verão, op. cit. p. 79

${ }^{5}$ DOSTOIÉVSKI, Fiódor. Dniévnik pisátelia. Moscou: ACT, 2007, p. 161.
} 
internacional, que repercutia sobre a Rússia e sobre os mais diversos contextos históricos. A necessidade de lidar com "esta influência, este apelo, esta pressão" resultaria em "aspectos russos de seus ensinamentos". Isto é: em reapropriações e reelaborações próprias de modelos estrangeiros, resultantes de diálogo tenso e singular com o contexto histórico nacional.

De acordo com expressão de Joseph Frank, o "prisma russo"7 "refratou" as influências ocidentais emprestando-lhes novas luzes e sombreados, novas "colorações", por meio de sínteses específicas. O processo atravessou as tradições e a formação históricas do país, recaindo, se desdobrando e sendo (re)elaborado em contundentes debates intelectuais e marcantes expressões artísticas. Processo que envolveria, fundamentalmente, a crítica social, e, entrelaçada à mesma, a produção e a crítica literárias.

Ao discutir a obra de Dostoiévski, Frank afirma ainda:

[...] para ele, como para muitos escritores russos a partir de Evguiénin Oniéguin, de Púchkin, a "história" devia ser entendida em termos de tipos literários historicamente representativos, mas criados de forma artística. Como escreveu sobre o homem do subsolo, 'essa figura não só pode, mas deve ser encontrada em nossa sociedade, dada as circunstancias sob as quais ela é geralmente formulada'. O homem do subsolo não era apenas um indivíduo particular, [...] mas alguém que expressou uma verdade simbólica sobre a natureza da sociedade russa como um todo. Assim [...] Dostoiévski criara personagens ficcionais que podem ser consideradas 'históricas' num sentido amplo, na medida em que encarnavam determinadas ideias e atitudes socioculturais. ${ }^{8}$

Ideias e atitudes socioculturais que se vinculam à criação literária, em obras de grande densidade artística, ideológica e histórica, ecoando através de uma galeria de "vozes plenivalentes", não necessariamente filiadas (e muitas vezes contrárias) aos pontos de vista advogados pelo autor, nos quadros de uma inovação artística que M. Bakhtin denominou "romance polifônico" . Através dele, personagens que "se encontra[ria]m em nossa sociedade" tomam a palavra. Elaboração literária e contexto histórico se encontram aqui de maneira bastante consciente e intencional, dando forma a que A. Cândido descreve enquanto um circuito dialético", tenso e dinâmico, entre texto e contexto, entre literatura e sociedade, entre contexto social e criação literária. ${ }^{10}$

\footnotetext{
${ }^{6}$ DOSTOIÉVSKI, Fiódor. Notas de inverno sobre impressões de verão, op. cit. p. 79.

${ }^{7}$ FRANK, Joseph. Pelo prisma russo: ensaios sobre literatura e cultura. Trad. Paula Cox Rolim. São Paulo: EDUSP, 1992.

${ }^{8}$ FRANK, Joseph. Dostoiévski: Os anos milagrosos (1865-1871). Trad. Geraldo G. de Souza. São Paulo: EDUSP, 2003, p. 570

${ }^{9}$ BAKHTIN, Mikhail. Problemas da poética de Dostoiévski. Trad. Paulo Bezerra. Rio de Janeiro: Forense Universitária, 2002.

${ }^{10}$ CÂNDIDO, Antônio. Literatura e sociedade: estudos de teoria e história literárias. São Paulo: Ed. Nacional, 1985.
} 


\section{Internacionalização: "maravilhas" literárias}

Segundo Andrzej Walicki, podemos averiguar no pensamento social russo do século XIX

uma fertilização mútua profundamente singular de ideias e influências; a rápida modernização de uma grande nação comprimida em um curto espaço de tempo; a curiosa coexistência dos elementos arcaico e moderno na estrutura social e nas formas de pensar; o rápido influxo de influências externas e a resistência a elas; o impacto, sobre a elite intelectual, das realidades sociais e das ideias da Europa Ocidental, por um lado, e a constante redescoberta de sua própria tradição nativa e realidades sociais, por outro. ${ }^{11}$

A literatura russa, produto exuberante e original de tal "fertilização", enquanto expressão social e artística, atravessou, nos anos 1880, um processo de difusão internacional em ampla escala, popularizando-se nos grandes centros do ocidente europeu. Reelaborando as "santas maravilhas" no âmbito de seu próprio contexto, a Rússia produziu "maravilhas" literárias que inverteram o sentido da troca, a direção dos "ventos" que levavam "esses Darwins e esses Mills" até o país: de Leste para Oeste, e não o contrário, "esses Dostoiévskis, Tolstóis e Gógols" conquistaram o mercado editorial europeu. Segundo Bruno Gomide,

O romance russo era a grande sensação europeia em meados da década de 1880. Na verdade, foi "inventado" para consumo internacional nesse período, quando surgem traduções em escala industrial e livros de críticas que, de forma pioneira, deram o tom [...] do que seria dito depois. ${ }^{12}$

A nova "coqueluche" literária (alçando sobretudo os nomes de Tolstói e Dostoiévski ao reconhecimento e à popularidade internacionais) "contaminaria" a intelectualidade brasileira ligada uma ampla gama de influências (também apropriadas e readaptadas) provenientes da Europa Ocidental. Lima Barreto, Clóvis Beviláqua, Artur Orlando e Euclides da Cunha, entre outros, escreveram a respeito dos (e foram influenciados por) literatos russos, entre os quais se destacava Dostoiévski. ${ }^{13}$

Desencadeou-se assim um processo no decorrer do qual a produção literária de um país considerado "atrasado" ou "periférico" - a Rússia autocrática, agrária, marcada pelo regime servil - transportou-se das "margens" de sua alegada "barbárie" para ocupar lugar de destaque no centro mesmo das "santas maravilhas". Ainda segundo Gomide,

\footnotetext{
${ }^{11}$ WALICKI, Adrzej. A history of russian thought: from the enlightenment to marxism. Stanford: Stanford University Press, 1979, p. XIV.

${ }^{12}$ GOMIDE, Bruno B. Da estepe à caatinga. O romance russo no Brasil. (1887-1936). São Paulo: Edusp, 2011, p. 17.

${ }^{13}$ Id. Ibid.
} 
De [...] ramo secundaríssimo no jardim das musas, a literatura russa passou a ser ingrediente decisivo dos debates artísticos e literários do fim de século. [...] é fenômeno raro [...] quando uma voga da periferia ou da semiperiferia do sistema literário internacional é capaz de se imiscuir na fortaleza decisória do centro, ultrapassar o aspecto epidérmico do modismo exótico e alterar a configuração de um determinado gênero. ${ }^{14}$

Para tanto, além da influência de críticos que se dedicaram à recepção e à reflexão a respeito do tema, contribuíram não apenas a qualidade, mas a originalidade da produção literária russa. Tal originalidade vai muito além das paisagens e cenários característicos, "exóticos" - pontuados pelo inverno rigoroso, neve abundante, tróicas, ou eventuais referências folclóricas -, mas envolve uma ampla galeria de tipos sociais; a recriação artística de um contexto marcado por especificidades culturais e históricas; a força estética, crítica e emocional da melhor literatura russa. Finalmente, de acordo com Gomide, num Ocidente imerso em referenciais positivistas, naturalistas e cientificistas haveria um público "ávido por pitadas de renascimento emocional fissurando o consenso positivista"15 que autores como Dostoiévski e Tolstói teriam a oferecer. O "renascimento emocional", no caso dostoievskiano, é composto por contundentes críticas e reflexões a respeito da "espessa sombra" de decadência moral e social que os modelos ocidentais ou modernizantes poderiam representar: afinal, "esses Mills e Darwins e Strausses por vezes tem uma visão muito estranha das obrigações morais de uma pessoa dos dias de hoje", e o romancista, crítico ao ateísmo, ao individualismo econômico e ao utilitarismo europeus, defenderia valores cristãos ortodoxos, supostamente resguardados no povo russo, como um fundamental, romântico e messiânico contraponto. Ao discutir os efeitos da modernidade em seu país, ou o "aspecto russo de seus ensinamentos", o egresso da "casa dos mortos" discute também os "ensinamentos" em si, e acaba por atingir, na década de sua morte (em 1881), o público internacional. Da "periferia" ao "centro", fronteiras rígidas entre países ditos "atrasados" e "avançados", "centrais" e "periféricos", se tornaram, assim, mais porosas, adquirindo maior mobilidade, maleabilidade e abrangência. O fluxo das influências e comércio culturais adquire mão dupla, na medida em que o romance russo incorporou e reelaborou, de maneira original, as contribuições do romance europeu, passando, por sua vez, a ser tema de debate e fonte de inspiração a oeste.

Se a segunda metade do século XIX foi marcada, na Rússia, por reformulações modernizantes, com destaque à libertação dos servos em 1861, não foram poucas as transformações ocorridas em outras "periferias". É o caso do Brasil, por exemplo, a partir da década de 1860:

\footnotetext{
${ }^{14}$ Id. Ibid. p. 81.

${ }^{15}$ Id. Ibid. 
a queda do Gabinete Zacarias (1868) e a fundação do Partido Republicano (1870); a Lei do Ventre Livre (1871); a Abolição (1888); a Proclamação da República (1889). Episódios marcantes no contexto de uma rápida redefinição do país - pontuado, no plano intelectual, por um "bando de ideias novas", segundo expressão de Sílvio Romero. A década ao longo da qual a literatura russa passou por amplo processo de difusão, coincidiu, no Brasil, com a publicação de algumas das obras mais importantes daquele que se consagraria, ainda em vida, enquanto um dos grandes expoentes da literatura nacional: Machado de Assis.

Os anos 1880, encerrados pela Abolição e a pela Proclamação (as quais se inscrevem, mais uma vez, em um complexo processo de modernização) foram marcados, logo em seus inícios, no plano artístico e cultural, pela publicação das Memórias Póstumas de Brás Cubas (1881). Brás, um rico e ocioso senhor de escravos, é uma reelaboração literária da elite nacional, ambígua e sarcasticamente situada, pelo romancista, entre tradições e modernidades. ${ }^{16}$ Por sua vez, F. Dostoiévski publicou algumas de suas obras mais importantes, incluindo Memórias do Subsolo (1864), Crime e Castigo (1866) e O Idiota (1868) no decurso da década de 1860, que representou, segundo o biógrafo Joseph Frank, seus "anos milagrosos"17 de atividade e criatividade literárias, culminando com a publicação de Os Demônios, em 1871. Conforme mencionado, ao longo destes mesmos anos 1860, sob o reinado do tsar Alexandre II, a Rússia atravessou um marcante processo de modernização, que incluiu, de maneira essencial, a abolição da servidão em fevereiro de 1861.

Os escritores brasileiros da segunda metade dos oitocentos, a exemplo de Machado, entraram em contato com, sofrendo influência da, literatura russa. O mesmo não se pode dizer, porém, a respeito dos literatos russos do período - enquanto para Machado, por exemplo, a literatura produzida no império tsarista não era referência estranha, Dostoiévski não esteve familiarizado com a produção literária brasileira de maneira geral, ou com a obra do "bruxo do Cosme Velho" de maneira específica. Não obstante, ambos os romancistas vivenciaram e (re) escreveram, através da ficção, os contextos de países que se modernizavam de acordos com "modelos" ou, para repetir a expressão dostoievskiana, "ensinamentos" importados e readaptados do ocidente europeu de forma ambivalente: resguardando e alterando, de maneiras específicas, suas tradições e contexto históricos.

Neste sentido, sugere-se uma reflexão a respeito de análises que tendem a apontar, na literatura brasileira e russa dos oitocentos, a presença de "ideias fora do lugar", típicas das "modernidades periféricas", enquanto componentes, supostamente essenciais, das expressões literárias e contextos históricos de ambos os países.

\footnotetext{
${ }^{16}$ Ver CHALHOUB, Sidney. Machado de Assis historiador. São Paulo: Companhia das Letras, 2003.

${ }^{17}$ FRANK, Joseph. Dostoiévski. Os anos milagrosos. op. cit.
} 


\section{O figurino}

Em Machado de Assis: um mestre na periferia do capitalismo R. Schwarz vincula a obra machadiana às permanências e rupturas da modernidade brasileira. Entre temas de interesse universal generalidades metafísicas e filosóficas - Machado lançaria um olhar irônico e agudo sobre o contexto nacional, reelaborando artisticamente as contradições de um Brasil que se modernizava e rompia com, ao mesmo tempo permanecendo fiel ao, passado oligárquico e escravista. Assim, o romancista valer-se-ia da ambivalência crítica, indireta e enviesada para expor e ridicularizar a multiplicidade de contradições que configuravam a existência de uma classe senhorial agarrada a privilégios tradicionais, e, ao mesmo tempo, pressionada pelas "santas maravilhas". Um "disparate" que resultaria em personagens como o senhor de escravos e inventor científico de emplastos anti hipocondríacos Brás Cubas. O personagem

a todo momento exibe o figurino de gentleman moderno, para desmerecêlo em seguida, e voltar a adotá-lo, configurando uma inconsequência [...]. É como se a conduta ilustrada fosse credora de respeitosa consideração, tanto quanto de escárnio, e funcionasse ora como norma indispensável, ora como trombolho - complementaridade que delineia um modo de ser. ${ }^{18}$

Um modo de ser, segundo sustenta Schwarz, pairando entre "respeitosa consideração" - uma vez que "tudo o que em nós existe de desenvolvido vem [...] daquela terra das santas maravilhas" - e o carregar incômodo de um "trombolho" deslocado da Europa. Uma maravilha/"fardo" que não apresentaria desdobramentos efetivos na consciência das elites nacionais. O acento satírico através do qual Brás revela as memórias de uma vida enfastiada, ainda de acordo com Schwarz, sugeririam que "ciência, filosofia e política aqui não passam de afetação."19

Cabe indagar, não obstante, em que medida a "afetação científica, filosófica e política" do contexto nacional (re)formulada nos escritos mordazes de Machado é específica, necessária ou principalmente local; ou em que medida as críticas machadianas podem e mesmo devem, sem prejuízo do local, ser compreendidas como críticas e respostas desconfiadas aos processos de modernização em sentido mais amplo.

A questão da "afetação científica", por exemplo, é inegável em Brás, assim como a "afetação' política e filosófica diz respeito à sociedade brasileira de maneiras cujas especificidades seria impossível ignorar. Por outro lado, tais "afetações", também de formas particulares, não estariam presentes em Paris - conforme Dostoiévski revela em suas Notas de Inverno, afirmando desconfiar de que os ideais de liberté, egalité, fraternité não passariam, na capital francesa e ponto nevrálgico do Ocidente

\footnotetext{
${ }^{18}$ SCHWARZ, Roberto. Machado de Assis: Um mestre na periferia do capitalismo. São Paulo: Ed. 34, 2000, pp. 1920.

${ }^{19}$ Id. Ibid. p.64.
} 
moderno, de abstrações afetadas? ${ }^{20}$ Seriam principal ou exclusivamente as versões russa e brasileira das "santas maravilhas" o que autores como Dostoiévski e Machado estariam colocando em questão, desconfiados e apreensivos (sobretudo no caso do romancista russo)? Seriam "o figurino de gentleman moderno" e "a conduta ilustrada" "trombolhos"/maravilhas submetidos a crédito respeitoso e a derrisória desconsideração, trajados e ultrajados somente ou sobretudo em regiões ditas "periféricas"? È possível, em alguma parte do mundo moderno ou tradicional uma conduta conforme, ou quase inteiramente conforme, o "figurino" mesmo onde o último fora fabricado e de onde era exportado? Autores como Arno Mayer, ao considerar a longevidade de tradições e ingerências aristocráticas na Europa ocidental contemporânea (em interações dialéticas com a modernidade ${ }^{21}$ ) indicam que não. Assim, não estariam "nus" - ao menos seminus - exibindo, à revelia, diferentes cicatrizes em seus corpos políticos, econômicos e intelectuais os países de onde a modernidade se originara e de onde se espraiava? Não existiriam Bacamartes, Brás Cubas e "homens do subsolo" vagando, em colorações particulares, pelo ocidente europeu?

Se, de acordo com Schwarz, "o escândalo das Memórias está em sujeitar a civilização moderna à volubilidade" 22 fazendo rir "das aquisições do Ocidente moderno" 23 , o próprio autor vem questionar: "a volubilidade é Brás Cubas? É todo o mundo? É o Brasil?"24.

Talvez não seja errôneo supor que a modernidade está "sujeita", basicamente, às sociedades, em seus dilaceramentos, que a incorporam, sob as reinvenções, choques, "escândalos" e interações e integrantes dos contextos e sujeitos históricos que a experimentam. Um fenômeno histórico se apresentando de maneiras alternativas, na Europa e fora dela, segundo circunstâncias, "escândalos" e entrelaçamentos distintos, sempre específicos, entre modernidade e tradição. Neste sentido, a volubilidade, como a modernidade, pode ser própria, mas não exclusiva.

Em trecho que aborda, literalmente, a questão do figurino, G.B. Sansom relata a respeito do Japão Meiji - exemplo singular e bem sucedido de modernização acelerada e, na contramão dos cânones liberais, comandada pelo Estado autoritário:

Portar roupas de estilo estrangeiro [...] era agora apropriado e up to date, e não ridículo como havia sido até período tão recente quanto 1859 , quando um inglês reportou que os japoneses de Iedo [capital Tokugawa, futura Tóquio] achavam engraçadíssimo o traje europeu [...]. Menos de vinte anos depois os jornais de Tóquio reportavam que os mais prósperos comerciantes da cidade eram os alfaiates de vestuários estrangeiros [...].

\footnotetext{
${ }^{20}$ DOSTOIÉVSKI, Fiódor. Notas de inverno sobre impressões de verão, op. cit

${ }^{21}$ MAYER, Arno J. A força da tradição: a persistência do Antigo Regime (1848-1914). Trad. Denise Bottmann. São Paulo: Companhia das Letras, 1987.

22 SCHWARZ, Roberto. Machado de Assis: Um mestre na periferia do capitalismo. op.cit. p. 56

${ }^{23}$ Id. Ibid. p. 57.

${ }^{24}$ Id. Ibid. p.62.
} 
Naturalmente, poucos japoneses, por volta de 1875, tinham condições de possuir um guarda-roupa ocidental completo, mas era comum trazer uma ou duas peças do vestuário estrangeiro. Combinações interessantes portanto surgiram, como um quimono sobre calças ou uma sobrecasaca por cima de um saiote de seda de duas abas, com dois sabres passados num cinturão; e isto obviamente foi um prato cheio para os humoristas japoneses. ${ }^{25}$

A combinação não se daria meramente entre quimonos e calças, mas entre a sacralidade do Imperador, ancorada na religião milenar xintoísta, e nos princípios (ou vernizes) de constitucionalismo e representatividade parlamentar ${ }^{26}$; entre "quimonos", "espadas samurais", crenças religiosas e formas de autoritarismo político tradicionais.

O Japão constitucional derrotaria a Rússia autocrática apenas seis anos depois de promulgada constituição japonesa; derrota que pareceu confirmar ao mundo em geral e à Rússia em particular o poder das "santas maravilhas" e suas fórmulas vencedoras - industriais, militares, econômicas e institucionais - e que contribuiu para desencadear questionamentos que culminaram na Revolução de 1905. E o tsar de todas as Rússias teria de fazer concessões e aceitar soluções de compromisso com a formação de uma assembleia legislativa e com a reconfiguração da autocracia em monarquia parlamentar.

O Brasil de 1888 e 1889, como o Japão constitucional, a Rússia e tantos outros destinos não (ou não inteiramente) europeus do mundo, combinaria, à sua maneira, as "calças" da Abolição e da República com os "quimonos" (certamente menos delicados e coloridos) do racismo - o último mal revestido pelas "calças curtas" de teorias científicas reapropriadas e transformadas em fórmulas racialistas; das "Itaguaís" provincianas e dos "doutores Bacamartes"; da elite culta e dos "cinquenta milhões [das camadas populares] a quem nós, que somos cem mil [membros da elite intelectual], até agora consideramos como sendo ninguém e de quem nossas revistas satíricas ainda hoje zombam pelo fato de não rasparem as barbas" 27 . O barbear foi um imperativo do tsar modernizador Pedro O Grande, visando adequar a aparência dos mujiques russos a padrões mais "civilizados". Nos trópicos, se as barbas de "cinquenta milhões" de brasileiros não foram alvos de zombaria e censura de "cem mil" privilegiados da elite nacional, os costumes, raça, trajes, manifestações culturais, ou, enfim, cada fio das longas "barbas" populares o seriam, no contexto da modernização excludente de fins de século.

Recorrendo ainda uma vez ao estudo de Sansom sobre interação de culturas, envolvendo modernidade e tradição no Japão Meiji,

\footnotetext{
${ }^{25}$ SANSOM, G. B. The Western World and Japan. A study in the interaction of European and Asiatic cultures. New York: Alfred A. Knopf, 1951, p. 382.

${ }^{26}$ PANNIKAR, K.M. A dominação ocidental na Ásia. Trad. Nemésio Salles. São Paulo: Paz e Terra, 1977.

${ }^{27}$ DOSTOIÉVSKI, Fiódor. Notas de inverno sobre impressões de verão, op. cit. p. 79.
} 
Em 1870 um pequeno grupo de intelectuais [japoneses] se engajaram na tradução do Código Civil Francês. Quando se depararam com a palavra droit civil a tradução minken foi sugerida - uma vez que min significa 'povo' e ken significa 'autoridade' ou 'privilégio'. Mas o povo teria 'direitos? O que isto significava? ${ }^{28}$

A mistura de vocábulos, como a mistura de figurinos, resulta, novamente, em combinações tão novas quanto originais. Direito; civil; autoridade; privilégio e - como combiná-lo, onde encaixá-lo? - povo. Se droit civil era uma "ideia fora do lugar" deslocada da Europa em direção ao leste, não por isso a modernização japonesa, sobretudo nos que diz respeito a aspectos científicos, industriais e militares, deixaria de se afirmar no contexto interno e internacional, abrindo caminho ao surgimento de uma nova potência.

Não há modelos fixos ou equilíbrios inteiramente estáveis no sempre cambiante contexto moderno ${ }^{29}$. Também não há um modelo, um grande parâmetro a ser seguido no despedir-se, sempre parcial, das tradições. É o que comprova, por exemplo, o próprio centro irradiador das "santas maravilhas" liberais, a França do século XIX, que conviveria com seus Napoleões e aonde a experiência republicana viria se instaurar de forma mais duradoura após o massacre da Comuna de Paris, tendo ainda a Terceira República, ao fim do século, sido marcada pela ascensão da direita católica, monarquista e antissemita, no calor do affaire Dreyfus. O ideal universalista liberal e democrático ou, para recorrermos ao Doutor Bacamarte, o "perfeito equilíbrio das faculdades mentais"30 ( no caso, sociais, cidadãs, democráticas) mostrou-se frágil, como se sabe, em inúmeros momentos, no próprio centro irradiador da "nossa luz e nossa esperança" (de acordo, ainda, com a irônica expressão dostoievskiana). Menos de cem anos após a elaboração das Notas de inverno do viajante russo, as ideologias de extrema-direita viriam negar "tudo o que em nós existe de desenvolvido", preservando e estimando, no entanto, as "santas maravilhas" tecnológicas, no contexto da Alemanha Nazista, por exemplo.

A breve referência a algumas contradições vivenciadas por grandes potências modernas diante das "santas maravilhas" tem por objetivo apontar a universalidade da falha de processos históricos efetivos diante do ideário - isto é, a não adequação perfeita ou total a ideias vinculadas à modernidade. Cada processo modernizante se desdobra em conflitos e ambivalências específicos a distintos contextos - sendo os pontos cegos no "figurino" "iluminado" tão particulares quanto múltiplos.

\section{4. "Fora do lugar"}

\footnotetext{
${ }^{28}$ SANSOM, G.B. op. cit. p. 312.

${ }^{29}$ Ver BERMAN, Marshall. Tudo o que é sólido desmancha no ar: a aventura da modernidade. Trad. Carlos Felipe Moisés e Ana Maria Ioriatti. São Paulo: Companhia das Letras, 2005.

${ }^{30}$ ASSIS, J. Machado de. "O alienista". 50 contos de Machado de Assis. São Paulo: Cia da Letras, 2007, p. 48
} 
Roberto Schwarz discute a vigência do "figurino" liberal no Brasil fazendo referência a "ideias fora do lugar" 31 apropriadas "na periferia" do centro irradiador das "santas maravilhas." Tais ideias seriam, a um só tempo, inafastáveis - devido à força e às pressões expansionistas da modernização - e impraticáveis, ou, segundo o autor, praticadas "em falso", de modo equívoco, moldado pela contingência histórica do trabalho escravo e das relações clientelistas vigentes no país. $O$ "desmerecimento" do "figurino" estaria ligado ao fato das ideias modernas haverem sido deslocadas para "fora do lugar", ao fato de o ideal tornar-se um "trombolho" uma vez carregado em direções "periféricas".

Formar-se-ia assim um pastelão ideológico no qual as ideias (ou ideais liberais) "sem perderem as pretensões de origem, gravitam segundo uma regra nova cujas graças, desgraças, ambiguidades e ilusões eram também singulares" ${ }^{\prime 2}$. Nesta singularidade, porém, o autor tende a enxergar o "figurino", no Brasil, como um verniz orgulhoso e equívoco que (mal) encobriria os, vamos chamá-los, "vícios de origem periféricos" que insistiriam em permanecer logo abaixo de uma débil camada de tinta modernizante. E, para comprometer ainda mais as "graças e desgraças singulares", estas necessitariam, para formar-se e manter-se, do esforço retorcido de um "torcicolo cultural em que nos reconhecemos" ${ }^{33}$. A singularidade é assim apontada como uma espécie de anomalia: um pescoço (que a princípio deveria figurar reto e estável) retorcido, dolorosamente entortado, atormentado por repuxões.

O que é apontado como singular confunde-se, por vezes, com algo aparentemente inominável, ou simplesmente aberrativo. Afinal, segundo o autor, "conhecer o Brasil era saber desses deslocamentos [de ideias], vividos e praticados por todos como uma espécie de fatalidade, para os quais, entretanto, não havia nome, pois a utilização imprópria dos nomes era sua natureza." 34

"Fatalidade", "esquisitice", "desajuste", "distorção", "deslocamento" ou "torcicolo" - palavras que carregam pressupostos negativos são utilizadas para descrever o processo. Tudo isto (des) amarrando, em perfeita desarmonia, "cinquenta milhões" de brasileiros simplórios e uma vanguarda conservadora e envernizada de contorcionistas "entortando" o que aparentemente figuraria, de outro modo - em seu "devido lugar" ao invés de "fora" dele - reto, íntegro, próprio, ou, na pior das hipóteses, menos marcado por contorções, fraturas e descontinuidades.

Seguindo a tendência de considerar "aberrativo" o contexto ambivalente em que se encontravam as sociedades não europeias do

\footnotetext{
${ }^{31}$ SCHWARZ, Roberto. Ao vencedor as batatas: forma literária e processo social nos inícios do romance brasileiro. São Paulo: Ed. 34, 2000, p. 26.

${ }^{32}$ Id. Ibid. p. 26

${ }^{33}$ Id. Ibid.

${ }^{34}$ Id. Ibid.
} 
século XIX e XX, Marshall Berman discorre sobre o mal-estar provocado na sociedade russa pela - assim denominada - "angústia do atraso e do subdesenvolvimento" 35 :

O que aconteceu nas áreas fora do Ocidente, onde, apesar das pressões crescentes do mercado mundial em expansão e do desenvolvimento de uma cultura mundial moderna [...] a modernização não estava ocorrendo? Nelas os significados da modernização teriam que ser mais complexos, paradoxais e indefinidos. Essa foi a situação da Rússia por quase todo o século XIX. Um dos fatores cruciais da história moderna da Rússia é que a economia do Império se estagnava [...] no momento em que em que as economias das nações ocidentais davam um salto espetacular à frente. Portanto, até o dramático surto industrial da década de 1890 os russos experimentavam a modernização como algo que não estava ocorrendo [...] ou ainda, quando ocorresse no país, como algo que acontecia das formas mais irregulares, vacilantes, flagrantemente destinadas ao fracasso ou estranhamente distorcidas. ${ }^{36}$

Novamente, temos a noção de distorção (e "estranha" distorção), enviesamento ou "desvio em relação ao modelo canônico anglo-francês" tomado como parâmetro unívoco de "avanço", "fracasso" ou "normalidade". O "fracasso", o "atraso", o "estranho" e a "angústia" entram na equação como resultados supostamente necessários. É como se, de acordo com certas visões sustentadas por autores como Schwarz e Berman, o "modelo original", ao entrar em contato com "solos" assim ditos "periféricos" e alterar-se, adquirisse formas não apenas diferenciadas, mas necessariamente "aberrativas", negativas, "condenadas ao fracasso"; como se o "cânone" não fosse apenas apropriado, mas, por assim dizer, "rebaixado" pela apropriação, o que tornaria os processos de modernização nas "áreas fora do Ocidente" necessariamente mais agônicos. Os ideais de liberdade, igualdade e fraternidade, enquanto "ideias fora do lugar', não encontrariam, em terras "subdesenvolvidas", o solo fértil para desenvolver-se, combinando exclusão social "arcaica" e capitalista com falta de liberdade, desrespeito às noções modernas de cidadania e participação política, entre outras "perversões" tão "estranhas", supostamente típicas do mundo não europeu - como se no chamado "centro" as perversões encarnadas no racismo, nas guerras coloniais e mundiais, por exemplo, fossem, de alguma forma, menos "distorcidas".

Berman chega a utilizar-se da expressão "modernidade bizarra e desvirtuada" 38 para referir-se ao processo de (não?) modernização russa, iniciado de forma autoritária, via reformas de Pedro o Grande.

\footnotetext{
35 BERMAN, Marshall. op. cit. p. 200.

${ }^{36}$ BERMAN, Marshall. Id. Ibid. Grifos meus.

${ }^{37}$ SCHWARZ, Roberto. Machado de Assis: Um mestre na periferia do capitalismo. op.cit. p. 38

${ }^{38}$ BERMAN, Marshall. op. cit. p. 207.
} 
A similaridade entre expressões utilizadas por Berman e Schwarz para descrever os processos de modernização russo e brasileiro, respectivamente, é espantosa. Afinal, os autores partem de premissas bastante semelhantes quanto ao que denominam "atraso" e "distorção periférica", relativos a processos de modernização não europeias.

Quanto ao suposto fato da modernidade na Rússia estar "flagrantemente destinada ao fracasso", cabe perguntar quais seriam as coordenadas, neste caso, a partir da quais se pode flagrar fracassos e sucessos como destinos inexoráveis. Trata-se de um julgamento - afinal, entre a noção de singularidade, de um lado, e "bizarria, desvirtuamento e fatalidade", de outro, há mais que uma diferença meramente nominal ou politicamente incorreta: há quase uma condenação apriorística.

Interessante é pensar que, sendo a modernidade um permanente "desmanche no ar"39, torna-se complicado, a princípio, o estabelecimento de um cânone de modernização, o que implicaria a ideia contraditória de "modernização canônica", quando, não obstante, a modernidade veio atingir, ou "desmanchar no ar", segundo o autor, certezas e cânones, colocando-as, de modo geral, em constante movimento.

As interpretações que têm como referência a oposição entre "centro" e "periferia" tendem a lançar um determinado olhar sobre a literatura "periférica" influenciado por parâmetros de comparação entre o "Ocidente avançado" e, basicamente, o restante das regiões do mundo, as quais figurariam enquanto "atrasadas". O ideal moderno "desvirtuado" ou a suposta "modernização bizarra" - este seria objeto da reflexão intelectual e social desenvolvida em países como a Rússia e o Brasil, dando origem a grandes elaborações literárias. "Um dos traços mais notáveis do subdesenvolvimento russo", por exemplo, ainda de acordo com Marshall Berman, seria a produção, "no espaço de apenas duas gerações de uma das maiores literaturas do mundo", além de "alguns dos mitos e símbolos mais duradouros da modernidade: o Homem Comum, o Homem Supérfluo, o Subterrâneo, a vanguarda, o Palácio de Cristal e, finalmente, os sovietes." ${ }^{40}$ Tais mitos e símbolos são, portanto, diretamente vinculados por Berman ao "subdesenvolvimento". De forma semelhante, e de acordo com o olhar de Schwarz, o gênio literário machadiano teria se desenvolvido, fundamentalmente, em torno dos "torcicolos" nacionais.

Partindo de premissas relativas a "ideias fora do lugar" Schwarz levanta hipóteses referentes à literatura brasileira especificamente, e à literatura russa de forma abrangente, afirmando:

"[Haveria no Brasil] uma gravitação complexa [...] na qual a ideologia hegemônica do Ocidente faz figura derrisória. O que é um modo, também, de indicar o alcance mundial que têm e podem ter as nossas esquisitices nacionais. Algo comparável, talvez, ao que se passa na literatura russa.

\footnotetext{
${ }^{39}$ Id. Ibid.

${ }^{40}$ Id. Ibid. p. 200. 
Diante desta, ainda os maiores romances do realismo francês fazem impressões de ingênuos. [...] É que a despeito de sua intenção universal, a psicologia do egoísmo racional, assim como a moral formalista, faziam do Império Russo efeito de uma ideologia 'estrangeira', e portanto localizada e relativa. De dentro de seu atraso histórico o país impunha ao romance burguês um quadro mais complexo." ${ }^{41}$

Schwarz vincula, assim, as literaturas russa e brasileira a processos ambíguos e acelerados da modernização oitocentista, considerando, porém, enquanto "esquisitices nacionais" os contextos ambivalentes em que estavam imersas as sociedades não europeias do século XIX e XX. Dois países distantes em termos de localização espacial e de contextos históricos, e o que os uniria, basicamente? O que Brasil, Rússia e a literatura produzida em ambas as nações poderiam ter em comum? A "esquisitice". Esta seria a chave fundamental de uma identidade remota. Não se trata, sequer, de estranhamento ou de diferenciação em relação ao modelo dominante das "santas maravilhas", mas de um conjunto "desconjuntado por natureza"42 - de supostas "aberrações". Pode-se construir a imagem de um circo de aberrações, cujas "esquisitices" são registradas, em páginas brilhantes, por literatos que, conforme a (má) sorte quis, nasceram entre as mesmas. Ou, como afirma Mashall Berman, a literatura seria "traço notável" do "subdesenvolvimento russo", leia-se, um subproduto genial de um gigantesco aleijão não "desenvolvido" adequadamente.

Fosse o Império Russo meramente "efeito [esquisito] de uma ideologia "estrangeira", ainda que entre aspas, a literatura russa, e aí destacamos o adjetivo russa, não teria a força de sua originalidade, ou, talvez, sequer existiria (não enquanto russa, ao menos). O Império tinha características próprias e irredutíveis, por maior que fosse a influência, o poder de sedução e pressão vindos do Oeste.

Schwarz segue afirmando:

A figura caricata do ocidentalizante, francófilo ou germanófilo, de nome frequentemente alegórico e ridículo, os ideólogos do progresso, do liberalismo e da razão, eram tudo forma de trazer à cena a modernização que acompanha o Capital. Estes homens esclarecidos mostram-se [...] lunáticos, ladrões, oportunistas, crudelíssimos, vaidosos, parasitas, etc. O sistema de ambiguidades assim ligada ao uso local do ideário burguês uma das chaves do romance russo - pode ser comparado aquele que escrevemos sobre o Brasil.. ${ }^{43}$

Os "lunáticos, oportunistas e ladrões esclarecidos" figuram nas obras de Machado de Assis e Dostoiévski com destaque, é certo. No trecho citado tem-se a impressão, porém, de que os "lunáticos, ladrões e

\footnotetext{
${ }^{41}$ SCHWARZ, Roberto. Ao vencedor as batatas. op. cit. p. 27.

${ }^{42}$ SCHWARZ, Roberto. Machado de Assis: Um mestre na periferia do capitalismo. op.cit. p. 38

${ }^{43}$ SCHWARZ, Roberto. Ao vencedor as batatas. op. cit. pp. 27-28.
} 
crudelíssimos" modernizadores seriam, apenas ou principalmente, subproduto das "esquisitices nacionais" recriadas pela literatura. Não obstante, é razoável considerar que o "sistema de ambiguidades ligada ao uso local do ideário burguês" também deu origem a personagens lunáticos e cruéis, retratados de forma nada condescendes, nas literaturas nacionais da "terra das santas maravilhas" - basta se pensar, por exemplo, nos Miseráveis de Victor Hugo ou nos libertinos onipresentes em Sade.

Schwarz aponta ainda, em Ao vencedor as batatas, que, se o ideário liberal europeu foi referência importante para a intelectualidade brasileira em meados dos oitocentos e inícios dos novecentos,

"monta-se [no país] uma comédia ideológica diferente da europeia. É claro
que a igualdade do trabalho, a igualdade perante a lei e de modo geral o
universalismo eram ideologias na Europa também; mas lá correspondia às
aparências, encobrindo o essencial - a exploração do trabalho. Entre nós,
as mesmas ideias seriam falsas num sentido diverso, por assim dizer,
original."

Tal originalidade é considerada não necessariamente menos desigual, injusta e exploratória; porém, uma vez eleita a "comédia ideológica europeia" como parâmetro, a diferença ou a originalidade da "periferia", do "fora do lugar" vem acompanhada de um adjetivo e de um parâmetro de medição: "atrasada". Tratar-se-ia, portanto, não apenas de uma originalidade, singular em misérias, vergonhas e tragédias, mas de uma originalidade "atrasada", de uma falsidade ("impostura" ou "desfaçatez") não necessariamente mais falsa, mas necessariamente mais "atrasada".

Um mestre na periferia do capitalismo registra um Brás especificamente brasileiro delineando-se entre um emaranhado de questões universalistas, atemporais e metafísicas que o personagem anuncia insistentemente. Assim, como ressalta Schwarz, não seria legítimo focar-se exclusivamente sobre as questões de um Brás "descarnado", acima de quaisquer análises de conteúdo histórico, sob risco de incorrer no equívoco, até certo ponto cômodo, de a historicizar a obra machadiana, amputando-lhe os contextos integrantes, recriados e alvejados pelo artista. O conceito de "periferia" em oposição ao de "centro", porém, pode ser problemático na medida em que apresenta o risco (e a tentação) de transformar uma relação instável, intercambiante e tensa, em oposição demasiado rígida. Onde estariam, por exemplo, os aspectos "periféricos" do "centro" europeu? Onde estariam, por outro lado, a gama de questões que, por definição, não têm e não podem ter um "centro" definido?

Para encaminhar tais discussões, propomos analisar e aproximar dois dos mais célebres personagens de Machado de Assis e Dostoiévski: Simão Bacamarte e o homem do subsolo.

${ }^{44}$ SCHWARZ, Roberto. Id. Ibid. p. 12. 


\section{Itaguaí, São Petersburgo e o universo: o alienista e o homem do subsolo ${ }^{45}$}

Simão Bacamarte (O Alienista, 1882) procura descobrir o "remédio universal"46 capaz de restituir aos conterrâneos itaguaienses e a toda humanidade "o perfeito equilíbrio das faculdades mentais." 47 Vaidade, soberba, covardia, prodigalidade, desonestidade moral ou política - o vasto repertório de idiossincrasias e falhas de caráter humanos passam a ser considerados, em determinado momento da saga alienante, sintomas inequívocos de loucura. Em pouco tempo a maior parte da cidade estaria internada no hospício dirigido pelo médico, a Casa Verde.

Ao longo da narrativa, o leitor é alertado para o fato, a princípio óbvio, de que Itaguaí colonial não é Paris. Mas o espaço e o tempo não constituíam limites aos experimentos universalizantes de nosso cientista, os quais deixariam "Itaguaí e o universo à beira de uma revolução" 48 . O estudioso reviraria pelo avesso, com teorias e métodos inovadores, o pacato cotidiano da cidade, a ponto de provocar, entre muitas reviravoltas, a rebelião dos "Canjicas". Um barbeiro, de alcunha Canjica, lidera a população rebelada contra o "despotismo científico do alienista" idealizador e comandante da "bastilha da razão humana" - a Casa Verde. $\mathrm{Na}$ província colonial ressoam ecos da Revolução Francesa, "dada a diferença de Paris a Itaguaí", os rebelados "podiam ser comparados aos que tomaram a Bastilha." ${ }^{49}$ A um evento histórico de relevância e efeitos internacionais, contrasta-se, de forma ridicularizante, uma rebelião que não conseguiria revolucionar, sequer, Itaguaí. Machado de Assis ironiza a apropriação do saber e das pretensões científicas europeias em um país distante, em termos que não envolvem apenas coordenadas espaciais, mas históricas (culturais, sociais, econômicas) em relação ao centro propulsor das modernas ciências e dos ideais de liberté, égalité e fraternité. O fato da narrativa se desenrolar em Itaguaí colonial reforça o abismo entre as pretensões universalizantes do cientista e o "terreno" onde pretende desenvolver seus experimentos - um país marcado pelo passado colonial e, no avançar de 1882 (ano de publicação do conto), pela escravidão.

Enquanto médico de formação europeia e especialista em patologias cerebrais, Bacamarte representa e incorpora a figura de um especialista e divulgador das "santas maravilhas" nos longínquos trópicos da América. Um membro da elite "patenteada" de "cem mil" brasileiros entre

\footnotetext{
45 Para uma comparação mais detalhada entre o Homem do subsolo e o alienista, entre outros personagens dostoievskianos e machadianos, ver PEREIRA, Ana Carolina Huguenin. "Meus senhores, a ciência é coisa séria': Cientificismo e ceticismo em Machado de Assis e Dostoiévski." In: REIS, Daniel A. e ROLAND, Denis (orgs). Intelectuais e modernidades. Rio de Janeiro: FGV. 2010.

${ }^{46}$ ASSIS, Machado de. op. cit. p. 41.

${ }^{47}$ Id. Ibid. p. 48

${ }^{48}$ Id. Ibid. p. 49

${ }^{49}$ Id. Ibid p. 59 
"cinquenta milhões" de conterrâneos "de modesta condição", boa parte dos quais ainda escravizados. Mais que isso, o alienista transforma-se em autoridade, cujo poder de intervenção recai diretamente sobre seus objetos vivos de estudo, aos quais se aplicam malogrados (muitas vezes absurdos, de onde se extrai efeito cômico) ensaios de cura.

Diante da turba enraivecida o sábio não estremece:

- Não dou razão dos meus atos de alienista a ninguém, salvo aos mestres e a Deus. [...] Poderia convidar alguns de vós [...] a vir ver comigo os loucos reclusos; mas não o faço, porque seria dar-voz razão do meu sistema, o que não farei a leigos, nem a rebeldes. ${ }^{50}$

É interessante notar que no discurso de Bacamarte os mestres da ciência, estivessem na Europa ou em Itaguaí, figuram ao lado de Deus. É a Ele que o Doutor compara-se em termos de poder de cura, sabedoria e decisão. Está claro que os "sistemas" dos "mestres" e de Deus seriam de ordens diferentes, mas, em comum, pairariam acima da "multidão", do tempo e do espaço, operando leis universais - de Paris a Itaguaí ou viceversa - sem pedir ou pedir ou prestar a "leigos", quer rebeldes, quer conformados, licenças ou razões.

Um dos primeiros mentecaptos recolhidos pelo alienista sofre de monomania religiosa: "chamando-se João de Deus, dizia agora ser o Deus João e prometia o reino dos céus a quem o adorasse, e as penas do inferno a outros." $\mathrm{O}$ "Deus João" era, conforme o senso comum reconhecia e a tradição consagrava, um delirante. Sua mania de grandeza só poderia ser fruto de uma mente perturbada, e seu destino é o isolamento em um asilo. Em ironia feroz contra o cientificismo e o racionalismo, mirando em seus "cem mil" adeptos brasileiros - caricaturados no próprio Bacamarte Machado de Assis reservará destino semelhante a seu herói. Sem o resguardo de Deus ou a orientação dos mestres, tão distantes de Itaguaí, "João Bacamarte de Deus", ao ensaiar tornar-se "Deus João Bacamarte" terminará só na Casa Verde que idealizara.

Segundo Boris Schnaiderman, "há uma proximidade muito grande entre a posição de Machado [em O Alienista] e a crítica de Dostoiévski ao racionalismo extremo de seu tempo. E tal como na obra deste, há uma verdadeira advertência sobre o desvario a que ela pode levar" 52 . Neste sentido, o ilustre doutor Bacamarte e o anônimo homem do subsolo podem ser apontados como alguns dos personagens machadianos e dostoievskianos que melhor dialogam entre si. Eles são, em grade medida, oposto e semelhante um do outro. Suas trajetórias, a princípio opostas e irreconciliáveis, acaba os conduzindo a um destino bastante semelhante.

\footnotetext{
${ }^{50}$ Id. Ibid p. 61. Grifos meus.

${ }^{51}$ Id. Ibid. p. 43.

${ }^{52}$ SCHNAIDERMAN, Boris. "O Alienista: um conto dostoievskiano?". Teresa: Revista de Literatura Brasileira [6] e [7]. São Paulo: Ed. 34: Imprensa Oficial, 2006, p. 270.
} 
Nas Memórias do Subsolo (1864) um funcionário petersburguense de baixa estratificação, porém instruído - isto é, marcado pela instrução moderna, tal como (em sua definição) "um camundongo de consciência hipertrofiada" 53 - encontra-se dilacerado entre o "belo e o sublime" própria mesquinharia, entre elevados ideais e a realidade brutal e desigual, a rígida hierarquização social e as arbitrariedades que marcavam o contexto russo oitocentista. Desafiando a racionalidade e a crença de que as questões sociais e espirituais que afligem o ser humano pudessem ser superadas pela cientifização ou racionalização, o memorialista tece contundentes e irônicas críticas:

Então [...] surgirão novas relações econômicas [...] calculadas com precisão matemática [...]. Erguer-se-á um palácio de cristal. [...], há de chegar o Reino da Abundância. Naturalmente não se pode garantir [...] que então tudo não seja terrivelmente enfadonho[...], mas, em compensação, tudo será extremamente sensato. [...]. [...] eu [...] não me espantaria [...] se em meio a toda sensatez surgisse algum cavaleiro de fisionomia [...] retrógrada e zombeteira, e pusesse as mãos na cintura, dizendo: [...] não será melhor dar um pontapé em toda esta sensatez unicamente para que todos esses logaritmos vão para o diabo, e para que se possa mais uma vez viver de acordo com nossa estúpida vontade? ${ }^{55}$

Ou ainda: "O homem, às vezes, ama terrivelmente o sofrimento. [...]. No Palácio de Cristal ele é simplesmente inconcebível. O sofrimento é dúvida, é negação, e o que vale um palácio de cristal do qual se possa duvidar? [...]."

O palácio ao qual Dostoiévski se refere é o edifício modernista de vidro e ferro erguido na capital inglesa em 1851 - o Palácio de Cristal, símbolo e templo da modernidade.$^{57}$ Em sua passagem pela Europa o autor visitara a Exposição Mundial de Londres sediada no edifício, na qual se exibia os últimos êxitos da tecnologia e das ciências. ${ }^{58}$ Sobre o Palácio Dostoiévski escreveu nas Notas de Inverno:

Sente-se uma força terrível, que uniu num só rebanho estes homens [...]; [...]. Não será este o ideal atingido? [...]. Não será preciso considerá-lo como verdade absoluta e calar-se [...]? Tudo isto é tão triunfante, altivo, que nos oprime o espírito. [...] Olha-se estas [...] milhões de pessoas que acorrem docilmente para cá, $[. .$.$] que se aglomeram [...] neste palácio$ colossal, e sente-se que aqui se realizou algo definitivo [...]. Isto constitui

\footnotetext{
${ }^{53}$ DOSTOIÉVSKI, Fiódor. Memórias do Subsolo. Trad. Boris Schnaiderman. São Paulo: Ed.34, 2000, p. 22.

${ }^{54}$ A expressão, utilizada repetidas vezes e com grande ironia pelo memorialista, se refere ao ensaio kantiano Observações sobre o sentimento do belo e do sublime (1764), e contrasta, no romance, ideais elevados ("sublimes") e as misérias e mesquinharias que atormentam o personagem e compõem seu "subsolo." Ver DOSTOIÉVSKI, Fiódor. Memórias do Subsolo. op.cit.

55 Id. Ibid. p. 38.

${ }^{56}$ Id. Ibid. pp. 48- 49.

${ }^{57}$ Para uma análise sobre a presença e a importância do Palácio de Cristal como símbolo da modernidade na obra dostoievskiana, ver BERMAN, Marshall. op. cit; e FRANK, Joseph. Dostoiévski: Os efeitos da libertação (1860-1865). Trad. Geraldo G. de Souza. São Paulo: EDUSP, 2002.

${ }^{58}$ FRANK, Joseph. Dostoiévski: Os efeitos da libertação. op. cit. p. 334
} 
não sei que cena bíblica, [...] uma profecia do Apocalipse [...]. Sente-se a necessidade de muita resistência para [...] não deificar Baal, isto é, não deificar o existente como sendo o ideal. ${ }^{59}$

"Não deificar Baal", não se inclinar diante do espírito "altivo" que erguera o "palácio colossal" é tarefa difícil, resistência árdua à tentação de "deificar o existente" - o falso deus materialista da modernidade industrial - "como sendo o ideal". O Palácio de Cristal, para aonde acorriam, dóceis e maravilhadas, pessoas de várias partes do mundo, simbolizaria o fim apocalíptico do espírito humano, pois, seduzidos por, e saciados com, as próprias realizações terrenas, não se teria mais o que buscar - deificando, enfim, "o existente como ideal". A submissão do mundo a "Baal" poderia criar um "rebanho único", dócil e universal, no qual as pessoas perderiam a identidade e a autonomia, inclinadas e satisfeitas perante o bezerro de ouro.

O ideal da transparência, a nitidez cristalina através da qual a vida em sociedade é compartilhada, não se podendo "mostrar a língua" nem mesmo "às ocultas", repugnam o memorialista, ao cercear discordâncias por meio de vigilância e controle. O racionalismo e o utilitarismo (as "novas relações econômicas calculadas com precisão matemática", a sensatez absoluta regulada segundo uma "tabua de logaritmos") ${ }^{60}$ são alvo de descrédito insistente ao longo do relato subterrâneo. Haveria sempre "algum cavaleiro de fisionomia pouco nobre, retrógrada e zombeteira", mandando "esses logaritmos para o diabo", e proclamando "nossa estúpida", pois nem sempre determinada pela razão, "vontade" humana.

O homem do subsolo é o cavaleiro de fisionomia pouco nobre e retrógrada, descrente e zombeteira, fazendo figas e caretas diante do "homem novo" da modernidade, capaz de fabricar maravilhas tecnológicas, construir palácios translúcidos e tábuas mágicas de logaritmos capazes de explicar, prever e controlar o comportamento humano. Ao mandar os "logaritmos" ao diabo, ele resiste ao racionalismo, e alerta os entusiastas do progresso, chamados de "criancinhas de peito" para os perigos e impossibilidades de aplicar verdades "matemáticas", puramente lógicas, ao comportamento humano. Um mundo perfeitamente sensato, previsível e sem sofrimento seria uma aberração, cedendo espaço ao fastio, à decadência, e, no limite, ao fim da experiência humana. A solidez definitiva de um palácio de vidro e ferro representaria, em última análise, uma traição aos próprios ideais modernos, que, a princípio, não reconhecem limites saciáveis e definições imobilizantes. A própria ciência moderna, mais especificamente, "desmancha no ar", a cada dia, certezas constituídas pelos próprios cientistas, já que sua trajetória é,

\footnotetext{
${ }^{59}$ DOSTOIÉVSKI, Fiódor. Notas de inverno sobre impressões de verão. op. cit. p. 114

${ }^{60}$ DOSTOIÉVSKI, Fiódor. Memórias do subsolo. op.cit. p. 37.

${ }^{61}$ Id. Ibid. p. 33.
} 
a princípio, ilimitada, num processo incessante de continuações e rupturas.

Mas a postura do homem do subsolo, apesar de desafiadora, não transcende a careta, cética e desfigurada, que o mantêm, por excesso de individualismo e voluntarismo, preso a um mundo próprio, subterrâneo.

O nosso alienista, entretanto, acreditava na possibilidade de construção de um "palácio" não propriamente de cristal, mas de grossas paredes e sólidas janelas verdes. A Casa Verde não teria a função de transparecer, para assim controlar, figas e caretas, dúvidas e negações. Em um movimento inverso, mas dentro de uma lógica semelhante a do "palácio de cristal", o "palácio" do Dr. Bacamarte, ao invés de expor, esconderia e isolaria, alienando desvios morais, fraquezas, covardias, contradições, todo comportamento que escapasse, enfim, da racionalidade encarnada nos ideais científicos do sábio brasileiro.

[...] Proclamo com insolência que todos esses belos sistemas, todas essas teorias para explicar à humanidade os seus interesses verdadeiros, normais - a fim de que ela, ansiando [...] por atingir essas vantagens, se torne bondosa e nobre, tudo isso não passa [...] de pura logística! ${ }^{62}$

Eis a sentença do homem do subsolo. Mas Bacamarte, armado de teorias supostamente capazes de desbravar o "continente da loucura" 63 e esclarecer os "interesses normais" da humanidade, acreditava na "logística", no "belo sistema" cuja pedra de toque seria a Casa Verde - o "palácio de cristal" convertido, ao fim do conto, no "subsolo" solitário do próprio doutor.

A população colonial, diante de experimento tão inovador, demonstra curiosidade e resistência, "tão certo é que dificilmente se desarraigam hábitos absurdos, ou ainda maus." 64 O narrador faz a observação ainda no início do conto, antes mesmo da Casa Verde ser construída, quando não passava de um projeto a ser aprovado pela vereança de Itaguaí. A resistência, daí por diante, com o aprofundamento das experiências científicas do alienista, só faria aumentar, mas desde já podemos escutar o eco da voz subterrânea de Dostoiévski, quando o homem do subsolo proclama:

Quereis desacostumar uma pessoa dos seus velhos hábitos e corrigir-lhe a vontade, de acordo com as exigências da ciência e do bom senso. [...] por que estais tão convictos de que não ir contra as vantagens reais, normais, asseguradas pelas conclusões da razão e pela aritmética, é de fato sempre vantajoso [...] e constitui uma lei para toda a humanidade? ${ }^{65}$

Ou ainda:

\footnotetext{
${ }^{62}$ DOSTOIÉVSKI, F. Memórias do subsolo. op. cit., p.35.

${ }^{63}$ ASSIS, Machado de. op. cit. p. 47.

${ }^{64}$ Id. Ibid. p. 40 . Grifos meus.

${ }^{65}$ DOSTOIÉVSKI, F. Memórias do Subsolo. op.cit. p. 45.
} 
Mesmo atualmente, embora o homem já tenha aprendido por vezes a ver tudo com mais clareza que na época bárbara, ainda está longe de ter-se acostumado a agir do modo que lhe é indicado pela razão e pela ciência. Mas, apesar de tudo, estais absolutamente convictos de que ele há de se acostumar a fazê-lo, quando tiver perdido de todo alguns velhos e maus hábitos quando o bom senso e a ciência tiverem educado e orientado completa e normalmente a natureza humana. ${ }^{66}$

Mas toda a humanidade seria beneficiada, segundo supunha Bacamarte, tão logo os princípios universais da ciência fossem aplicados à "alma humana'. A correção dos "velhos e maus hábitos" (nas palavras de Dostoiévski), ou, (nas palavras de Machado de Assis) dos "hábitos absurdos, ou ainda maus" itaguaienses vai se intensificando, e fracassando, à medida que o alienista aplica suas teorias e tenta incutir na população as leis do bom senso - o "perfeito equilíbrio das faculdades mentais". O médico lota o hospício e apavora os objetos de seus experimentos - seres humanos distantes da mentalidade e do centro irradiador da ciência, mas, além disso, e por definição, aquém (ou muito além) do ideal científico que a eles procura se aplicar; afinal, as pessoas não são ideais, não são fenômenos regulares ou fórmulas matemáticas.

Os "alienados" do Dr. Bacamarte não cessariam de fazer "figas e caretas" retrógradas e desafiadoras até que a Casa Verde, "palácio" onde as idiossincrasias humanas deveriam ser exterminadas, fosse esvaziada para abrigar, apenas, o próprio alienista.

Segundo Schnaiderman,

Deixando de lado o episódico, o acessório, Machado em O alienista mergulha nos grandes temas da condição humana. E ao mesmo tempo, tão diferente de Dostoiévski em termos de construção literária, aproxima-se deste no modo de encarar a psique humana e as limitações que lhe são impostas. ${ }^{67}$

"Os grandes temas da condição humana" são tratados por ambos os autores de acordo com coordenadas históricas que dizem respeito à Rússia e ao Brasil de maneiras bastante específicas, sem prejuízo da universalidade das temáticas abordadas e reelaboradas, no processo de criação artística, em suas obras.

Seja em Itaguaí, em São Petersburgo ou Paris, as pessoas, transformadas em objetos vivos do conhecimento "alienante", são constituídas por "estúpidas vontades" não reformuláveis na "Casa Verde" ou no "Palácio de Cristal". Elas permaneceriam desafiantes em relação a (seja qual for) o "palácio" estabelecido - o "original" europeu ou as "adaptações" russas e brasileiras do mesmo. A adequação do comportamento ou mesmo da "alma" humanos a uma espécie de "tábua

\footnotetext{
${ }^{66}$ Id. Ibid. p. 37. Grifos meus.

${ }^{67}$ SCHNAIDERMAN, Boris. op. cit. p. 273
} 
de logaritmos" falharia no Brasil, na Rússia (dentro das características peculiares aos complexos países) ou na "terra das santas maravilhas". Neste sentido, "o palácio" - cristalino ou alienante -, na visão de ambos os autores, estaria sempre "fora do lugar", não havendo "lugar", em parte alguma, para sua concretização ou êxito.

Temos diante de nós o "bruxo' (figura do imaginário universal) do "Cosme Velho" (coordenadas precisas e mesmo cômicas na precisão familiar, prosaica). A "bruxaria" incorpora e transcende o "Cosme Velho", exercendo seu feitiço de lá a Petersburgo, ou onde quer que um ser humano aos seus "efeitos" se disponha a entregar-se. E volta. Um circuito - no qual o "Cosme Velho" não desaparece, apenas se move, no gravitar "mágico" da "bruxaria" que o conduz ao mundo e que conduz o mundo até (e através de) ele. Neste sentido, nota-se certa diluição, sem descaracterização, de fronteiras internas e externas, e do próprio registro do advento histórico da modernidade, que se combina, inevitavelmente, com contextos tradicionais ingleses, brasileiros, franceses, russos e assim por diante. O circuito que liga e complexifica, lança e retorna "os líderes do pensamento progressista europeu", e, por outro lado, o "aspecto russo [ou brasileiro, chinês, etc] de seus ensinamentos" - no contexto da "fertilização mútua" apontada por Walicki - transpõe fronteiras rígidas entre "centro" e "periferia". A literatura russa em particular, atravessada pelo "aspecto russo" (ou se preferirmos, pela "refração" de "seus ensinamentos" através do "prisma" nacional) invade o "centro", em fins do século XIX, com suas próprias versões e debates a respeito das "santas maravilhas". No âmbito de tais transposições, é desejável estarmos atentos para que o "periférico" não se sobreponha à "centralidade" dos "mestres" nacionais.

Personagens como o homem do subsolo e Simão Bacamarte (a exemplo de cada personagem dostoievskiano e machadiano) estão entrelaçados, conforme se expressara Machado de Assis, ao "sentimento íntimo do seu tempo e do seu país" ${ }^{68}$ - ligados, de forma indissociável, à história e ao "solo" dos países nos quais "germinaram", sem prejuízo de se tratarem, em seus aspectos trágicos e cômicos, elevados ou aviltados, de personagens de alcance (social e emocional) de extensão mais ampla, mundialmente identificável, como demonstra a grande repercussão internacional da literatura russa ainda nos oitocentos.

As críticas elaboradas por Dostoiévski não se referem apenas ou principalmente a supostos "desvios" russos (entendidos de forma negativa, enquanto "desvirtuamentos" ou "bizarrias", como sugere Berman) em relação ao "modelo original" do Ocidente - segundo disseminada tendência de, tomando o padrão moderno europeu como parâmetro, enxergar nas especificidades russas, e de tantas outras nações fora do contexto imediato da Europa ocidental, "desvios" suspeitos e

${ }^{68}$ ASSIS, J. Machado de. "Instinto de Nacionalidade". Obra Completa, vol. III. Rio de Janeiro: Nova Aguilar, 1994. p.806. 
desqualificantes, "retardos" inevitáveis, fracassos históricos e inabilidades ideológicas. Antes, é o modelo mesmo, em suas múltiplas versões, que está sob o questionamento, a zombaria, a admiração "extática e horrorizada" do artista.

Uma vez apropriadas, e cabe citar como exemplo o caso específico da Rússia, dilacerada pelas famosas discussões entre ocidentalistas e eslavófilos, as perspectivas modernas sofriam "mutações" e adquiririam caráter singular, gerando reflexões e propostas próprias, por meio de

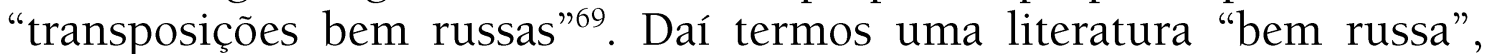
"bem moderna" e "bem universal".

A literatura é um grande exemplo disto que podemos averiguar, de maneiras diferenciadas, através de Dostoiévski e Machado, entre outros. Isto é: se os literatos russos, por exemplo, foram profundamente influenciados pela cultura das "santas maravilhas", com a qual Dostoiévski tanto se preocupou, eles criaram expressões artísticas próprias, de força e originalidade, discutindo a modernidade e contribuindo para a criação de propostas alternativas de modernização a partir de seu próprio prisma.

Recebido em 29/06/2017

Aprovado em 11/08/2017

${ }^{69}$ KOYRÉ, Alexander. La philosophie et le problème national en Russie au début du XIXe. siècle. Paris: Gallimard, 1976 , p.15. 